\title{
Assessment of Echocardiographic Findings in Patients with Asymmetric Presentation of Retinopathy of Prematurity
}

\section{Asimetrik Özellik Gösteren Prematüre Retinopatisi Olgularında Ekokardiyografik Bulguların Değerlendirmesi}

\author{
(D) Yasin Özcan1, (D) Hüseyin Gümüş², (D) Mehmet Çıtırık³, (D) Murat Çiftel4
}

${ }^{1}$ Yeditepe University Medical School, Yeditepe Speciality Hospital, Department of Ophthalmology, İstanbul, Turkey

2Harran University Faculty of Medicine, Department of Children's Health and Diseases, Division of Neonatology, Şanlıurfa, Turkey

3 University of Health Sciences Turkey, Ulucanlar Eye Training and Research Hospital Ankara, Turkey

4Şanlıurfa Training and Research Hospital, Clinic of Children's Health and Diseases, Division of Pediatric Cardiology, Șanlıurfa, Turkey

\begin{abstract}
Introduction: This study aimed to investigate the relationship between symmetric and asymmetric retinopathy of prematurity (ROP) and echocardiographic parameters.

Methods: This prospective study included 85 premature infants classified into three groups based on the presence/ absence of ROP: 32 premature infants without ROP (group A), 26 premature infants with asymmetric ROP (group B), and 27 premature infants with symmetric ROP (group C). Cardiac parameters were measured using M-mode echocardiography.

Results: The mean gestational age (GA) was $32.03 \pm 1.5$ weeks in group A, $30.69 \pm 2.5$ weeks in group $B$, and $31.5 \pm 2.9$ weeks in group C. The mean birth weight (BW) was $1802 \pm 312$ gram (g) in group $A, 1606 \pm 470 \mathrm{~g}$ in group $\mathrm{B}$, and $1642 \pm 456 \mathrm{~g}$ in group C. As a result of the one-way ANOVA, the mean GA and BW were significantly higher in group $A(p=0.03)$. No significant differences were found in the interventricular septal wall thickness (diastolic and systolic) left ventricular internal dimension (diastolic and systolic), left ventricular posterior wall thickness (diastolic and systolic), ejection fraction, stroke volume, and fractional shortening among the three groups $(p=0.12, p=0.93, p=0.64, p=0.91, p=0.48, p=0.83, p=0.56$, $p=0.72, p=0.32, p=0.73, p=0.21$, respectively).
\end{abstract}

Conclusion: Global cardiac function does not seem to have an effect in the asymmetric presentation of the eyes in patients with ROP.

Keywords: Retinopathy of prematurity, asymmetry, echocardiography

\section{öZ}

Amaç: Bu çalıșmada simetrik ve asimetrik özellik gösteren prematüre retinopatisi (PR) olguları ile bu olgulara ait ekokardiyografik parametreler arasındaki ilişkinin incelenmesi amaçlandı.

Yöntemler: Prospektif özellikteki bu çalıșmaya, PR varlığına göre 3 gruba ayrılan toplam 85 prematüre bebek dahil edildi. PR gelişmeyen 32 hasta grup A, her iki gözde asimetrik özellikte PR gelișen 26 hasta grup B ve her iki gözde simetrik özellikte PR gelișen 27 hasta grup C olarak sınıflandırıldı. Kardiyak parametreler M-mod ekokardiyografi kullanılarak ölçüldü.

Bulgular: Ortalama (ort.) doğum haftası (DH) grup A'da $32,03 \pm 1,5$ hafta, grup B'de 30,69 $\pm 2,5$ hafta ve grup C'de $31,5 \pm 2,9$ hafta idi. Ort. doğum ağırlığı (DA) grup A'da $1802 \pm 312$ gram (g), grup B'de $1606 \pm 470$ g ve grup C'de $1642 \pm 456$ g idi. Gruplar arasında yapılan one-way ANOVA analizinde ort. DH ve $D A$, grup A'da anlamlı olarak daha yüksek idi $(p=0,03)$. Gruplar arasındaki diyastolik ve sistolik interventriküler septum duvar kalınlığı, diyastolik ve sistolik sol ventrikül internal boyutları, diyastolik ve sistolik sol ventrikül arka duvar kalınlıkları, ejeksiyon fraksiyonu, sistolik volümler ve fraksiyonel kısalma ölçümleri arasında istatistiksel olarak anlamlı bir fark saptanmadı (sırasıyla, $p=0,12, p=0,93, p=0,64, p=0,91$, $p=0,48, p=0,83, p=0,56, p=0,72, p=0,32, p=0,73, p=0,21)$.

Sonuç: Genel kardiyak fonksiyonunun PR gelişen olguların gözlerinde hastalığın asimetrik olarak karşımıza çıkması üzerinde herhangi bir etkisi olmadığı gözlendi.

Anahtar Kelimeler: Prematüre retinoaptisi, asimetri, ekokardiyografi

Cite this article as/Atıf: Özcan Y, Gümüș H, Çıtırık M, Çiftel M. Assessment of Echocardiographic Findings in Patients with Asymmetric Presentation of Retinopathy of Prematurity. İstanbul Med J 2020; 21(4): 262-5.

(C) Copyright 2020 by the University of Health Sciences Turkey, Istanbul Training and Research Hospital/istanbul Medical Journal published by Galenos Publishing House.

(c) Telif Hakkı 2020 Sağlık Bilimleri Üniversitesi İstanbul Eğitim ve Araștırma Hastanesi/Istanbul Tıp Dergisi, Galenos Yayınevi tarafından basılmıștır. 


\section{Introduction}

Retinopathy of prematurity (ROP) is a vasoproliferative disorder and one of the leading causes of preventable blindness in children both in developing and developed countries $(1,2)$. The increasing survival rate of preterm infants through advanced neonatal care has led to an increase in the incidence of ROP $(3,4)$. Many risk factors have been identified for the development of ROP, including low gestational age (GA), low birth weight (BW), prolonged oxygen supplementation, neonatal infection, hypoxia, blood transfusion, sepsis, anaemia and apnoea that may lead to haemodynamic instability associated with the development of ROP $(2,5,6)$. Functional echocardiography is a non-invasive method allowing the rapid assessment of cardiac output and haemodynamic status in preterm new borns. Haemodynamic assessment using echocardiography has the potential to identify the underlying cause of structural heart disease, and ventricular performance plays a significant prognostic role in the identification of clinical status and long-term outcomes in preterm neonates (7-9). Of all cardiac disorders, patent ductus arteriosus has been determined as the sole factor associated with ROP (10). Although ROP is commonly stated as a symmetric disease, a very small percentage of infants may have asymmetric presentation. Therefore, this study aimed to investigate the relationship between symmetric and asymmetric presentation of ROP in any stage and echocardiographic parameters. The hypothesis of the study was that abnormal cardiac parameters indicating haemodynamic instability that do not cause any clinical disturbance may lead to asymmetric presentation of ROP.

\section{Methods}

This single-centre, prospective study was carried out from August 2019 to October 2019 in a tertiary referral centre for ROP.

The study protocol was approved by Harran University Ethics Committee (approval number: 74059997-050.04.04), and the study was carried out in accordance with the Declaration of Helsinki. Written informed consent was obtained from the parents or legal guardians of the patients prior to enrolment and before any measurements were taken. All patients were Turkish Caucasians.

\section{Patients}

Preterm infants with $\mathrm{BW} \leq 1500 \mathrm{~g}$ or $\mathrm{GA} \leq 32$ weeks were included in this study. Infants with BW >1500 gram (g) or GA >32 weeks with a history of admission to a neonatal intensive care unit due to unstable clinical course were also included. The initial fundus examination was performed at 4-6 weeks after birth. An ophthalmologist (YO), with experience in the screening and treatment of ROP, performed all examinations. The retinal findings were classified according to the current International Classification of ROP (11). When ROP of any stage was detected, examinations were repeated at weekly or biweekly intervals depending on the retinal findings, until a completely vascularised peripheral retina was obtained. An eyelid speculum and scleral indentation were used in all examinations. The premature infants were assigned to three groups based on the presence and symmetry of ROP. Premature infants without ROP were defined as group A, those with asymmetric ROP as group B, and those with bilateral symmetric ROP as group C. Echocardiographic measurement was performed one day after the ROP screening to eliminate alterations in echocardiography outcomes caused by scleral depression and topical medications for pupil dilatation.

None of the patients had a history of heart disease or any surgery. Patients with a history of taking systemic medications, especially anticoagulants and antiplatelet drugs which may cause alterations in the cardiac output, or a history of previous blood transfusions were excluded.

\section{Echocardiographic Examination}

In all subjects, two-dimensional, M-mode, pulsed and colour flow Doppler echocardiographic examinations (Vivid 7 pro, GE, Horten, Norway, $3 \mathrm{MHz}$ transducer) were performed by a cardiologist who was blinded to the clinical details and results of the other investigations of each case. During echocardiography, a 1-lead electrocardiographic recording was employed continuously. The systolic function of the left ventricle was evaluated using M-mode echocardiography in the parasternal long-axis view. Cardiac parameters were measured using M-mode echocardiography that allows evaluation of the interventricular septal (IVS) wall thickness, left ventricular internal dimension (LVID), left ventricular posterior wall (LVPW) thickness on both diastolic and systolic intervals, ejection fraction (EF), systolic volume (SV), and fractional shortening (FS).

\section{Statistical Analysis}

Data from all groups were expressed as mean \pm standard deviation. The Kolmogorov-Smirnov test was used to assess the conformity of data to normal distribution. Differences in the echocardiographic parameters between the three groups were evaluated using one-way analysis of variance (ANOVA), where applicable. The Bonferroni test was used as a post hoc test after one-way ANOVA. The level of significance was set at $<0.05$. All statistical analyses of the study were performed using SPSS for Windows (SPSS Inc., Chicago, IL, USA).

\section{Results}

A total of 85 premature infants were divided into three groups based on the presence and symmetry of ROP. group A was composed of 32 premature infants without ROP, group B was composed of 26 premature infants with asymmetric ROP, and group C consisted of 27 premature infants with symmetric ROP.

The gender pedilection among groups was 18 boys (56\%) and 14 girls (44\%) in group A, 18 boys (69\%) and 8 girls (31\%) in group B, and 15 boys (56\%) and 12 girls (44\%) in group C. No difference was determined between the groups with respect to gender $(p>0.05)$

The mean GA was $32.03 \pm 1.5$ weeks in group A, $30.69 \pm 2.5$ weeks in group $B$, and $31.5 \pm 2.9$ weeks in group C. The mean BW was $1,802 \pm 312 \mathrm{~g}$ in group $A, 1,606 \pm 470 \mathrm{~g}$ in group $B$, and $1,642 \pm 456 \mathrm{~g}$ in group $C$. As a result of the one-way ANOVA, the mean GA and BW were significantly higher in group $A$, whereas no significant differences were found between groups $B$ and $C$ in terms of the mean GA and BW ( $p=0.03,0.15$, respectively).

The echocardiographic measurements of the three groups are summarised in Table 1. No significant differences in IVS (diastolic and systolic), LVID (diastolic and systolic), LVPW (diastolic and systolic), EF, SV, 
Table 1. Echocardiographic measurements and comparison data of three groups of premature infants

\begin{tabular}{|c|c|c|c|c|}
\hline & $\begin{array}{l}\text { Group A }(n=32) \\
(\text { mean } \pm \text { SD) }\end{array}$ & $\begin{array}{l}\text { Group B }(n=26) \\
(\text { mean } \pm \text { SD) }\end{array}$ & $\begin{array}{l}\text { Group C }(n=27) \\
(\text { mean } \pm \text { SD) }\end{array}$ & p \\
\hline IVSd (mm) & $0.4 \pm 0.13$ & $0.3 \pm 0.13$ & $0.3 \pm 0.11$ & $p=0.12$ \\
\hline IVSs (mm) & $0.5 \pm 0.18$ & $0.5 \pm 0.14$ & $0.5 \pm 0.16$ & $p=0.93$ \\
\hline LVIDd (mm) & $2 \pm 0.37$ & $1.9 \pm 0.42$ & $1.9 \pm 0.36$ & $p=0.64$ \\
\hline LVIDs (mm) & $1.2 \pm 0.29$ & $1.2 \pm 0.32$ & $1.2 \pm 0.25$ & $p=0.91$ \\
\hline LVPWd (mm) & $0.4 \pm 0.11$ & $0.3 \pm 0.15$ & $0.4 \pm 1$ & $p=0.48$ \\
\hline LVPWs (mm) & $0.5 \pm 0.18$ & $0.5 \pm 0.1$ & $0.5 \pm 0.13$ & $p=0.83$ \\
\hline EDV (mL) & $14.5 \pm 8.38$ & $12.3 \pm 7.9$ & $13.3 \pm 6.8$ & $p=0.56$ \\
\hline ESV (mL) & $4.2 \pm 2.81$ & $3.6 \pm 2.8$ & $4.1 \pm 2.3$ & $p=0.72$ \\
\hline EF (\%) & $71 \pm 6.80$ & $70.5 \pm 7.3$ & $68 \pm 9$ & $p=0.32$ \\
\hline $\mathrm{SV}(\mathrm{mL})$ & $9.5 \pm 4.6$ & $8.5 \pm 5.2$ & $9.1 \pm 4.9$ & $p=0.73$ \\
\hline FS (\%) & $38.2 \pm 5.71$ & $38 \pm 5.8$ & $35.8 \pm 7.4$ & $p=0.21$ \\
\hline
\end{tabular}

and FS values were found between the groups $(p=0.09,0.15,0.12,0.93$, $0.64,0.91,0.48,0.83,0.56,0.72,0.32,0.73,0.21$, respectively).

\section{Discussion}

Different tools such as the measurement of blood pressure, capillary refill time, and urinary output and lactate analysis, functional echocardiography, and near-infrared spectroscopy are used to assess haemodynamic status in preterm infants at risk for haemodynamic instability (12). Clinical assessment of cardiovascular status is unreliable in neonates, while conventional echocardiography is commonly used for haemodynamic assessment (13). In this study, the investigation focused on whether haemodynamic instability may have an effect on the symmetric presentation of ROP using an echocardiographic method with different measurements. No significant difference was determined among the three groups in terms of all mean echocardiographic measurements, indicating cardiac contractibility and haemodynamic health status. No abnormal echocardiographic parameters which may indicate haemodynamic instability were detected in any of the three groups. Furthermore, neither the presence nor the asymmetry of ROP was associated with any of the echocardiographic parameters. Interestingly, on initial examination, either mild or moderate ROP was determined in patients with asymmetric presentation of ROP and no patients with symmetric ROP progressed to stage 3 disease or developed other diseases requiring treatment during the follow-up period.

Many risk factors have been identified as predisposing factors for the development of ROP. The only proven cardiological risk factor associated with the development of ROP is patent ductus arteriosus (13). In this study, no significant differences were determined in the echocardiographic parameters including IVS (diastolic and systolic), LVID (diastolic and systolic), LVPW (diastolic and systolic), EF, SV, and FS values in the three groups. Several studies have assessed different cardiac parameters in preterm and full-term infants, but none of these were designed to investigate the relationship with the presence or asymmetry of ROP (14).

Ciccone et al. (15) reported that IVS diameter, left ventricular (LV) endsystolic diameter, left atrial diameter, and EF values were not significantly different between infants born prematurely with very low BW $(<1,500$ g) and those born at term with weight appropriate for GA, although the size of the left ventricle and altered LV diastolic function were significant in premature infants with a very low BW. Levy et al. (16) reported that echocardiographic parameters including LV, global longitudinal strain, and global longitudinal systolic strain rates remained unchanged in both uncomplicated preterm infants and infants with bronchopulmonary dysplasia (BPD) that affects primarily right ventricular (RV) function, whereas the RV free wall longitudinal strain, RV free wall longitudinal strain rate, and IVS strain rate were significantly lower in infants with BPD.

The main limitation of this study was the use of echocardiography alone to measure reliable quantitative parameters of ventricles in preterm infants.

\section{Conclusion}

The results of this study revealed that abnormal cardiac parameters do not accompany the presence and asymmetry of ROP. Global cardiac function does not seem to have an effect on the asymmetric presentation of the eyes in patients with ROP. Echocardiographic assessment alone is not a practical method to clarify haemodynamic instability in premature infants with and without ROP. Further studies with larger patient groups are needed to confirm these findings.

\section{Ethics}

Ethics Committee Approval: The study protocol was approved by Harran University Ethics Committee (approval number: 74059997-050.04.04), 
and the study was carried out in accordance with the Declaration of Helsinki.

Informed Consent: Written informed consent was obtained from the parents or legal guardians of the patients prior to enrolment and before any measurements were taken.

Peer-review: Externally peer-reviewed.

Authorship Contributions: Surgical and Medical Practices - Y.Ö., Mu.Ç.; Concept- Y.Ö.; Design - Y.Ö.; Data Collection or Processing - Y.Ö., H.G., Mu.C.; Analysis or Interpretation - H.G.; Literature Search - H.G.; Writing - Y.Ö., M.Ç.

Conflict of Interest: No conflict of interest was declared by the authors.

Financial Disclosure: The authors declared that this study received no financial support.

\section{References}

1. Gomella TL, Cunningham MD, Eyal FG, Tuttle DJ, editors. Neonatology: Management, procedures, on-call, problems. Mcgraw Hill \& Lange, 2013.p.844-9.

2. Ozcan PY, Çıtırık M, Özçalıșkan S. Current Epidemiology, Pathophysiology and risk Factors in retinopathy of prematurity. Ret-Vit 2016; 24: 263-70.

3. Valentine PH, Jackson JC, Kalina RE, Woodrom De. Increased survival of low birth weight infants: Impact on the incidence of retinopathy of prematurity. Pediatrics 1989; 84: 442-5.

4. Gibson DL, Sheps SB, Uh SH, Schechter MT, McCormick AQ. Retinopathy of prematurity-induced blindness: Birth weight-specific survival and the new epidemic. Pediatrics 1990; 86: 405-12.

5. Darlow BA, Hutchinson JL, Henderson-Smart DJ, Donoghue DA, Simpson JM, Evans NJ, et al. Prenatal risk factors for severe retinopathy of prematurity among very preterm infants of the Australian and New Zealand Neonatal Network. Pediatrics 2005; 115: 990-6.

6. Chen Y, Xun D, Wang YC, Wang B, Geng SH, Chen H, et al. Incidence and risk factors of retinopathy of prematurity in two neonatal intensive care units in North and South China. Chin Med J (Engl) 2015; 128: 914-8.
7. Breatnach CR, Levy PT, James AT, Franklin O, El-Khuffash A. Novel echocardiography methods in the functional assessment of the newborn heart. Neonatology 2016; 110: 248-60.

8. Lewandowski AJ, Bradlow WM, Augustine D, Davis EF, Francis J, Singhal A, et al. Right ventricular systolic dysfunction in young adults born preterm. Circulation 2013; 128: 713-20.

9. Lewandowski AJ, Augustine D, Lamata P, Davis EF, Lazdam M, Francis J, et al. Preterm heart in adult life: cardiovascular magnetic resonance reveals distinct differences in left ventricular mass, geometry, and function. Circulation 2013; 127: 197-206.

10. Mitsiakos G, Papageorgiou A. Incidence and factors predisposing to retinopathy of prematurity in inborn infants less than 32 weeks of gestation. Hippokratia 2016; 20: 121-6.

11. Fierson WM, Saunders RA, Good W, Palmer EA, et al. Screening examination of premature infants for retinopathy of prematurity. Pediatrics 2013; 131: 18995.

12. Escourrou G, Renesme L, Zana E, Rideau A, Marcoux MO, Lopez E, et al. How to assess hemodynamic status in very preterm newborns in the first week of life?. J Perinatol 2017; 37: 987-93.

13. Lopez L, Colan SD, Frommelt PC, Ensing G], Kendall K, Younoszai AK, et al. Recommendations for quantification methods during the performance of a pediatric echocardiogram: a report from the Pediatric Measurements Writing Group of the American Society of Echocardiography Pediatric and Congenital Heart Disease Council. J Am Soc Echocardiogr 2010; 23: 465-95; quiz 576-7.

14. Eriksen BH, Nestaas E, Hole T, Liestøl K, Støylen A, Fugelseth D. Myocardial function in term and preterm infants. Influence of heart size, gestational age and postnatal maturation. Early Hum Dev 2014; 90: 359-64.

15. Ciccone MM, Cortese F, Gesualdo M, DI Mauro A, Tafuri S, Mancini G, et al. The role of very low birth weight and prematurity on cardiovascular disease risk and on kidney development in children: a pilot study. Minerva Pediatr 2016 Jun 29.

16. Levy PT, El-Khuffash A, Patel MD, Breatnach CR, James AT, Sanchez AA, et al. Maturational patterns of systolic ventricular deformation mechanics by twodimensional speckle-tracking echocardiography in preterm infants over the first year of age. J Am Soc Echocardiogr 2017; 30: 685-98. 